\title{
Pemetaan Daerah Rawan Kebakaran Di Lahan Gambut Berdasarkan Pola Sekuens Titik Panas Di Kabupaten Pulang Pisau Kalimantan Tengah
}

\author{
Mapping of Risk Fire in Peat Land based on Hotspot Sequential Pattern Mining in District of \\ Pulang Pisau, Kalimantan Tengah \\ Anissa Rezainy ${ }^{\mathrm{a}}$, Lailan Syaufina ${ }^{\mathrm{b}}$, Imas Sukaesih Sitanggang ${ }^{\mathrm{c}}$ \\ ${ }^{a}$ Program Studi Ilmu Pengelolaan Sumberdaya Alam dan Lingkungan, Sekolah Pascasarja, Institut Pertanian Bogor, Kampus IPB \\ Baranangsiang Bogor \\ ${ }^{\mathrm{b}}$ Departemen Silvikultur, Fakultas Kehutanan, Institut Pertanian Bogor, Kampus IPB Dramaga Bogor 16680 \\ ${ }^{c}$ Departemen Ilmu Komputer, Fakultas Matematika dan Ilmu Pengetahuan Alam, Institut Pertanian Bogor, Kampus IPB Dramaga \\ Bogor 16680
}

\section{Article Info:}

Received: 27 - 02 - 2020

Accepted: 17 - 07 - 2018

Keywords:

Composite mapping analysis, land and forest fire, sequential pattern mining, hotspot.

Corresponding Author: Anissa Rezainy

Program Studi Ilmu Pengelolaan Sumberdaya Alam dan

Lingkungan, Sekolah Pascasarja, Institut Pertanian Bogor;

Email:

anissarezainy@yahoo.co.id

\begin{abstract}
Land and forest fire is one of the major causes of Indonesia's deforestation, who has a significant impact to the environment, loss of conservation, air pollution and economic loss. This research develop a spatial modelling of factors that can drive the forest fire. Spatial model of vulnerability of land and forest fire is developed by the composite mapping analysis method. Hotspot datasets used in this research is the results of data mining processing, with sequential pattern mining technique which to find the relationships between the occurances of sequential event and its pattern that often appear. From the six variables influences land and forest fire there are four variables that have significant impacts in the study area, as follows: forest zone, depth of peatland, distance of irrigation, and distance of road. The fire in the area of study occurs many times in the peatland area with the depth of 400-800 cm. Land and forest fire occurs frequently in 100900 meters from irrigation and land and forest fire also occurs frequently in 1-4 $\mathrm{km}$ form the road. Land and forest fire occurs frequently in protected forest.
\end{abstract}

How to cite (CSE Style $8^{\text {th }}$ Edition):

Rezainya A, Syaufina L, Sitanggang IS. 2020. Pemetaan daerah rawan kebakaran di lahan gambut berdasarkan pola sekuens titik panas di Kabupaten Pulang Pisau Kalimantan Tengah. 10(1): 66-76. http://dx.doi.org/10.29244/jpsl.10.1.66-76.

\section{PENDAHULUAN}

Kebakaran hutan dan lahan yang terjadi setiap tahun di Indonesia dilatarbelakangi adanya kebutuhan penggunaan lahan yang terus bertambah untuk pertanian dan permukiman. Kebakaran hutan dan lahan bukan merupakan fenomena baru pada hutan hujan tropis (Hoscilo et al., 2011). Bertambahnya kejadian kebakaran hutan dan lahan dibuktikan dengan semakin meluasanya wilayah yang terbakar dan frekuensi kejadian kebakaran dalam beberapa dasawarsa terakhir (Cattau et al., 2016). Menurut Wooster et al. (2012); Hoscilo et al. (2011) kebakaran hutan dan lahan di Kalimantan sebagian besar merupakan hasil aktivitas kegiatan manusia yang berkaitan dengan deforestasi hutan (perkebunan kelapa sawit, pulp dan kertas), perubahan penggunaan lahan, persiapan produksi pertanian yang dilakukan masyarakat dengan cara membakar lahan. 
Kebakaran hutan dan lahan yang terjadi pada tahun 2015, merupakan kejadian terburuk dalam periode dua dasawarsa terakhir, dengan predikasi besaran lahan yang hilang sebesar 2.61 juta hektar (Tacconi, 2016). Tingginya kejadian kebakaran yang berulang setiap tahun diketahui menimbulkan kerugian pada bidang ekonomi, kesehatan dan ekologi sehingga diperlukan sistem pengelolaan untuk mengendalikan kejadian kebakaran. Secara umum sistem pengelolaan pengendalian kebakaran dibagi menjadi tiga komponen yaitu, pencegahan, pemantauan dan penanggulangan. Komponen terpenting adalah pencegahan kejadian kebakaran. Menurut Cortez dan Morais (2007) sistem peringatan dini merupakan elemen kunci untuk mencegah kebakaran hutan dan lahan. Pengembangan sistem peringatan dini (early warning sistem) dan kajian evaluasi resiko kebakaran, cukup efektif dalam mencegah munculnya kebakaran (Chuvieco et al., 2014).

Penentuan tingkat kerawanan daerah kebakaran merupakan salah satu cara dalam mencegah terjadinya kebakaran hutan dan lahan. Tingkat kerawanan kebakaran hutan pada suatu wilayah dapat didekati dengan pemodelan matematik yang menghubungkan kejadian kebakaran dengan faktor-faktor yang dapat memengaruhi kejadian kebakaran (Mukti et al., 2016; Mapilata et al., 2013; Setiawan et al., 2004; Samsuri 2008).

Titik panas merupakan indikasi yang memungkinkan terjadinya kebakaran yang merupakan rekaman dari sensor MODIS (Moderate Resolution Imaging Spectroradiometer) yang dapat diakses oleh masyarakat. Pada penelitian Prasasti et al (2012) mengungkapkan bahwa dengan banyaknya jumlah titik panas tidak selalu menggambarkan makin luas area yang terbakar. Pembaharuan pada penelitian kali ini adalah penggunaan titik panas yang diperoleh dari hasil data mining. Penelitian mengenai titik panas berdasarkan pola sekuens dalam menganalisis faktor-faktor yang dapat memengaruhi kebakaran hutan belum banyak dilakukan. Pola sekuens titik panas merupakan hasil pengolahan data mining dengan menggunakan metode Sequence Pattern Mining. Pola sekuens digunakan pada data yang jumlahnya besar dan bertujuan untuk menemukan hubungan yang menarik antara kejadian peristiwa yang berurutan dan pola yang sering muncul (Zhao dan Bhowmick, 2003). Pola sekuens diharapkan dapat menemukan pola-pola berurutan dalam kumpulan urutan data kejadian (Nurulhaq dan Sitanggang, 2015). Adanya pola titik panas yang berurutan, menjadi indikator kuat dilapangan yang mengindikasikan terjadinya kejadian kebakaran hutan dan lahan. Diharapkan model spasial kebakaran pada daerah penelitian yang terbentuk dapat berguna sebagai upaya pencegahan kebakaran dan informasi dalam membuat keputusan dan pengelolaan kebakaran lahan gambut di Indonesia.

Penelitian ini, bertujuan untuk melakukan pemetaan daerah rawan kebakaran pada lahan gambut berdasarkan faktor-faktor yang dapat memengaruhi kebakaran dengan data pola sekuens titik panas.

\section{METODE}

\section{Lokasi dan Waktu Penelitian}

Wilayah studi penelitian ini adalah Kabupaten Pulang Pisau, Provinsi Kalimantan Tengah (Gambar 1). Data yang digunakan dalam penelitian ini berupa citra landsat 8 tahun 2015, peta rupa bumi indonesia dari Badan Informasi Geospasial (BIG) skala 1 : 250000 Kabupaten Pulang Pisau, dan peta sebaran lahan gambut Provinsi Kalimantan Tengah dari Wetland International tahun 2002. Perangkat lunak yang digunakan pada penelitian ini yaitu ArcGIS 10.2, Quantum GIS, dan SPSS.

\section{Analisis Data}

Analisis spasial yang dilakukan meliputi proses overlay, manipulasi, pengkelasan, penyusunan skor, pembobotan, dan pembuatan model sehingga menghasilkan peta kerawanan kebakaran hutan. Faktor - faktor penyebab kebakaran hutan dan lahan disajikan pada Tabel 1. Data pola sekuens titik panas diperoleh dari penelitian Istiqomah pada tahun 2015, dengan bantuan perangkat lunak ArcGIS, dikonversi menjadi data 
shapefile. Peta sebaran pola sekuens titik panas diolah dengan fasilitas density tools untuk membuat peta kepadatan titik panas yang akan digunakan untuk membangun model spasial tingkat kerawanan kebakaran hutan dengan metode CMA (Composite Mapping Analysis).

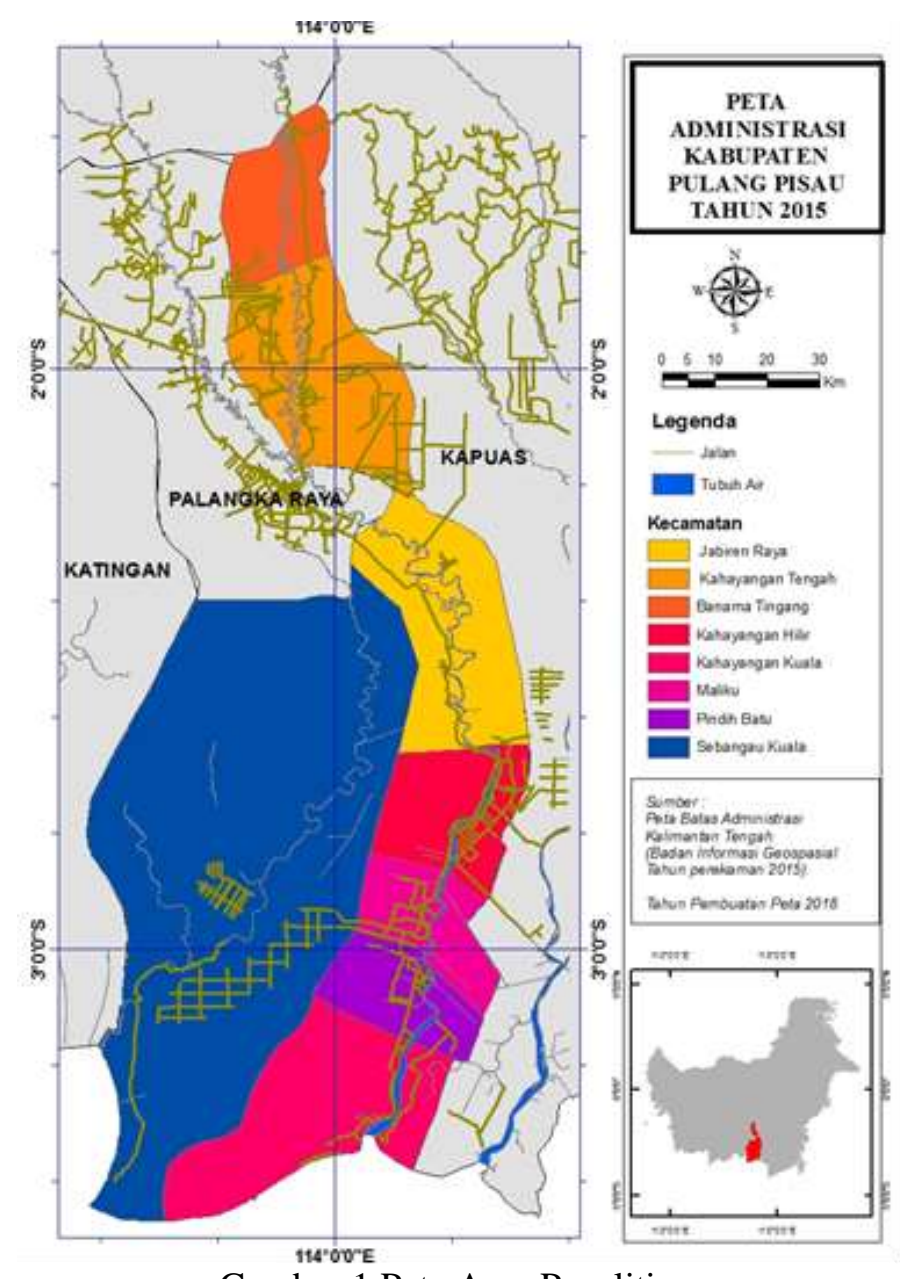

Gambar 1 Peta Area Penelitian.

Tabel 1 Faktor - faktor yang mempengaruhi kebakaran hutan dan lahan.

\begin{tabular}{ll}
\hline Faktor & Sub Faktor \\
\hline & Area Penggunaan Lain \\
& Kawasan Suaka Alam \\
Fungsi Kawasan & Hutan Lindung \\
& Hutan Produksi Terbatas \\
& Hutan Produksi Tetap \\
& Hutan Produksi yang dapat dikonversi \\
\hline & Perkebunan \\
Tutupan Lahan & Ladang \\
& Hutan \\
\hline Jangkauan Jarak jalan & Semak Belukar \\
\hline Jangkauan jarak kanal & Analisa multiple ring buffer dengan interval $1 \mathrm{~km}$ \\
\hline Jangkauan jarak sungai & Analisa multiple ring buffer dengan interval 100 meter \\
\hline \multirow{2}{*}{ Kedalaman Gambut } & Analisa multiple ring buffer dengan interval $1 \mathrm{~km}$ \\
\hline
\end{tabular}




\begin{tabular}{ll}
\hline Faktor & Sub Faktor \\
\hline $50-100(80 / 20)$ \\
$100-200(60 / 40)$ \\
$200-400(60 / 40)$ \\
$400-800(60 / 40)$ \\
$800-1200(60 / 40)$ \\
\hline
\end{tabular}

Nilai skor pada masing-masing sub faktor dapat dihitung menggunakan formula Jaya et al., (2007) dengan menggunakan formula (1) dan (2)

$$
\begin{gathered}
\mathrm{X}_{\mathrm{i}}:\left[\frac{O i}{E i}\right] \times \frac{100}{\sum_{\overline{E i}}^{O i}} \\
\mathrm{E}_{\mathrm{i}}:\left[\frac{T X F}{100}\right]
\end{gathered}
$$

dimana : $\mathrm{x}_{\mathrm{i}}=$ skor kelas (sub faktor) pada masing-masing variable, $\mathrm{O}_{\mathrm{i}}=$ jumlah titik panas yang ada pada masing-masing kelas (observed titik panas), $\mathrm{E}_{\mathrm{i}}=$ jumlah titik panas yang diharapkan pada masing-masing kelas (expected titik panas), $\mathrm{T}=$ total jumlah titik panas, $\mathrm{F}=$ persentase luas pada masing-masing kelas

Rescalling score adalah cara untuk menstandarkan nilai skor pada masing-masing variabel pada rentang nilai tertentu. Salah satu cara melakukan standarisasi skor skala menggunakan formula Jaya et al. (2007), dimana masing-masing kelas diberi skor pada rentang 10 sampai dengan 100 dengan persamaan berikut ;

$$
\text { score }_{R . \text { out }}=\left(\frac{\text { Score }_{\text {E input }^{-}} \text {Score }_{\text {E min }}}{\text { Score }_{E \text { Max }}-\text { Score }_{E \text { min }}}\right) *\left(\text { Score }_{R \text { Max }}-\text { Score }_{R \text { Min }}\right)+\text { Score }_{R \text { min }}
$$

dimana :

Score $\mathrm{R}_{\text {out }}$ : nilai skor hasil rescalling

Score $\mathrm{E}_{\text {input }}$ : niai skor dugaan

Score $\mathrm{E}_{\min }$ : nilai minimal skor

Score $\mathrm{E}_{\max }$ : nilai maksimal skor dugaan

Score $\mathrm{R}_{\max }$ : nilai skor tertinggi hasil rescalling

Score $\mathrm{R}_{\min }$ : nilai skor terendah hasil rescalling

Pada analisis ini bobot setiap peubah untuk mengindentifikasi derajat pengaruhnya terhadap kerawanan kebakaran hutan dan lahan dilakukan dengan pendekatan kuantifikasi dengan menggunakan metode analisis pemetaan komposit (Composit mapping analysis/CMA). Hubungan antara jumlah titik panas per $\mathrm{km}^{2}$ dengan faktor-faktor penyusun kerawanan kebakaran hutan dan lahan dianalisis untuk menurunkan nilai skor masing-masing faktor. Faktor-faktor yang memiliki korelasi yang relatif lebih tinggi dibandingkan dengan faktor lain dipilih dan digunakan untuk menyusun model regresi linear berganda. Model regresi dinyatakan bagus apabila model yang terbentuk memiliki signifikansi $<0.005$.

\section{Uji Kelayakan Model}

Uji validasi terhadap model spasial yang telah dibangun dilakukan dengan menggunakan data pola sekuens titik panas pada tahun 2015 sebanyak 187 titik. Data kebakaran tersebut dilakukan uji akurasi pada peta kerawanan kebakaran yang telah diperoleh dari model yang berhasil dibuat. Jika model dapat memplotposisikan daerah hasil kerawanan kebakaran pada kelas kerawanan yang sangat tinggi lebih dari 75\% maka model dapat diterima sebagai model spasial kerawanan kebakaran pada Kabupaten Pulang Pisau. 


\section{HASIL DAN PEMBAHASAN}

Analisis hubungan skor setiap variabel dengan kepadatan titik panas dilakukan melalui proses spasial dan statistik. Data tabel hasil intersect antara kepadatan titik panas (variabel tidak bebas) dengan variabelvariabel yang memengaruhi kebakaran dilakukan analisis regresi linear. Analisis regresi dilakukan untuk mendapatkan model dengan nilai koefisien determinasi $\left(\mathrm{R}^{2}\right)$ terbaik. Nilai skor komposit disusun berdasarkan semua peubah yang memiliki $\mathrm{R}^{2}$ tertinggi. Beda nyata antar kelas dapat diketahui dengan melihat nilai signifikansi setiap kelas terhadap kelas pembanding dimana dua kelas dinyatakan berbeda nyata apabila kelas-kelas tersebut memiliki nilai signifikansi $<0.005$. Tabel 2 menujukkan nilai koefisien dan signifikansi hasil intersect skor rescalling terhadap kepadatan titik panas.

Tabel 2 Hasil regresi linear pada skor rescalling terhadap kepadatan titik panas pola sekuens.

\begin{tabular}{lrr}
\hline \multicolumn{1}{c}{$\begin{array}{c}\text { Variabel - variabel yang memengaruhi } \\
\text { kebakaran hutan }\end{array}$} & Coefficients & Sig. \\
\hline Fungsi Kawasan $\left(\mathrm{X}_{1}\right)$ & 0.050 & $0.000^{(\mathrm{a})}$ \\
Kedalaman Gambut $\left(\mathrm{X}_{2}\right)$ & 0.180 & $0.000^{(\mathrm{a})}$ \\
Jarak Jalan $\left(\mathrm{X}_{3}\right)$ & 0.073 & $0.000^{(\mathrm{a})}$ \\
Jarak Kanal $\left(\mathrm{X}_{4}\right)$ & 0.047 & $0.000^{(\mathrm{a})}$ \\
Jarak Sungai $\left(\mathrm{X}_{5}\right)$ & 0.018 & 0.082 \\
Tutupan Lahan $\left(\mathrm{X}_{6}\right)$ & 0.025 & 0.011 \\
\hline
\end{tabular}

${ }^{\mathrm{a}}$ Signifikan pada taraf $0.5 \%$

Berdasarkan hasil uji model terbaik yang terdapat pada tabel 2, variabel yang signifikan memiliki pengaruh terhadap kepadatan titik panas pada taraf nyata $0.5 \%$, yaitu fungsi kawasan, kedalaman gambut, jarak jalan, dan jarak kanal. Persamaan skor komposit yang diperoleh adalah $\mathrm{y}=0.050 \mathrm{X}_{1}+0.180 \mathrm{X}_{2}+$ $0.073 \mathrm{X}_{3}+0.047 \mathrm{X}_{4}$. Penyusunan bobot masing-masing variabel disusun berdasarkan proporsi masing-masing koefisien korelasi dari regresi linear terhadap total seluruh koefesien regresinya. Nilai bobot dapat dilihat pada Tabel 3. Skor komposit kerawanan kebakaran berada pada interval 3.498 sampai 77.652. Terdapat 3 kelas kerawanan kebakaran di wilayah studi. Nilai interval skor komposit dan jumlah titik panas validasi tiap kelas kerawanan ditampilkan pada Tabel 4.

Kabupaten Pulang Pisau memiliki tingkat kerawanan kebakaran dengan proporsi kelas kerawanan tertinggi pada kelas tinggi. Kelas kerawanan tertinggi sebesar $76 \%$ dari seluruh total area kajian dengan jumlah pola sekuens titik panas sebanyak 143 titik. Proporsi kelas kerawanan rendah pada kelas rendah sebesar $4 \%$ dari seluruh total area kajian dengan jumlah pola sekuens titik panas sebanyak 7 titik. Peta kelas kerawanan kebakaran pada Kabupaten Pulang Pisau ditunjukkan pada Gambar 2.

Tabel 3 Nilai koefisien dan bobot penyusun untuk skor komposit model.

\begin{tabular}{lll}
\hline Variabel & Coefficients & Bobot \\
\hline Fungsi kawasan $\left(\mathrm{X}_{1}\right)$ & 0.050 & 0.142 \\
Kedalaman Gambut $\left(\mathrm{X}_{2}\right)$ & 0.180 & 0.514 \\
Jarak jalan $\left(\mathrm{X}_{3}\right)$ & 0.073 & 0.208 \\
Jarak kanal $\left(\mathrm{X}_{4}\right)$ & 0.047 & 0.134 \\
\hline
\end{tabular}

Tabel 4 Data kelas kerawanan kebakaran di Kabupaten Pulang Pisau.

\begin{tabular}{lccc}
\hline $\begin{array}{l}\text { Kelas Kerawanan } \\
\text { Kebakaran }\end{array}$ & Interval Skor Komposit & $\mathrm{Oi}^{(\mathrm{a})}$ & Persentase Akurasi Model \\
\hline Rendah & $3.498-28.216$ & 7 & $4 \%$ \\
Sedang & $28.217-52.935$ & 37 & $20 \%$ \\
Tinggi & $>52.936$ & 143 & $76 \%$ \\
\hline
\end{tabular}

${ }^{\mathrm{a}} \mathrm{Oi}$ :Jumlah pola sekuens titik panas 


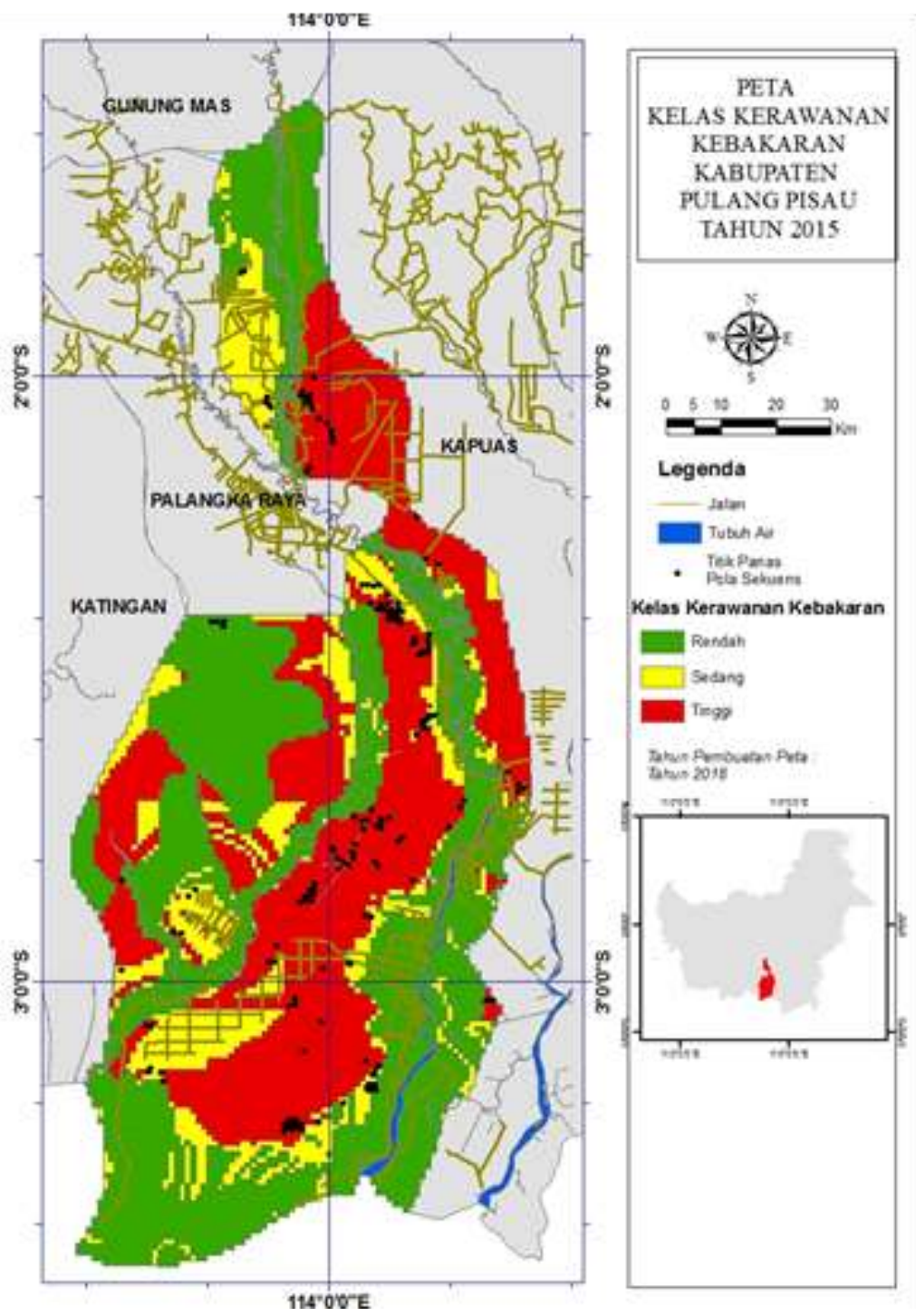

Gambar 2 Peta kelas kerawanan hutan dan lahan di Kabupaten Pulang Pisau Tahun 2015.

Kedalaman gambut merupakan variabel yang berpengaruh terhadap kebakaran di Kabupaten Pulang Pisau. Persentase dan luas daerah kerawanan pada area studi digambarkan pada Tabel 5. Persentase kerawanan paling tinggi pada kelas kerawanan tinggi berada pada kedalaman gambut 400-800 cm, dengan persentase sebesar 64\% dari seluruh total kejadian kebakaran di area studi. Persentase kerawanan kebakaran paling rendah pada kelas rendah berada pada tanah Gambut dengan kedalaman 800-1200 cm, dengan persentase sebesar 3\% dari seluruh total kajian kebakaran. Kejadian kebakaran pada area studi banyak terjadi pada gambut dengan kedalaman 400-800 cm, apabila dibandingkan dengan kelas kedalaman yang lain.

Kebakaran pada gambut dalam merupakan ciri kebakaran di lahan gambut, karena kebakaran tidak dapat diprediksi dan bergerak lambat karena tidak diakibatkan oleh angin. Praktek pengaliran air pada lahan gambut (seperti perkebunan kelapa sawit, perkebunan karet, pembukaan untuk lahan pertanian, dan penebangan tebang pilih) berkontribusi tinggi menyebabkan daerah tersebut gampang terbakar oleh api jika tidak dilakukan pengelolaan yang baik (Sumarga, 2017). Pada musim kering lahan gambut yang kering, cenderung lebih sensitif terhadap api dikarenakan materialnya yang mudah terbakar (Sumarga, 2017).

Kebakaran di lahan gambut memiliki resiko sulit dideteksi dan sulit dikendalikan dibandingkan kebakaran pada jenis tanah lain. Kebakaran di lahan gambut menembus lapisan bawah dan membentuk lubang corong, kemudian api akan menyebar secara horizontal (Syaufina, 2008). Gambut yang mengalami konversi pada temperatur yang tinggi, sedikit kelembapan, menyebabkan meningkatnya evaporasi gambut selama musim panas sehingga menyebabkan kandungan air gambut menurun pada tingkat terendah (Dohong 
et al., 2017). Gambut yang terbakar cenderung berlangsung secara terus menerus bahkan sampai berbulanbulan, terutama pada musim kering (Shi et al., 2014). Akibat kadar air gambut menurun menyebabkan terjadinya oksidasi gambut dan mempercepat dekomposisi dan mineralisasi yang menyebabkan subsiden gambut, kebakaran dan meningkatnya emisi karbon (Dohong et al., 2017).

Hasil penelitian pada Tabel 6 menunjukkan bahwa persentase jarak dari kanal dengan tingkat kerawanan yang paling tinggi pada kelas kerawanan tinggi berada pada jarak antara 200-900 meter dari kanal dengan persentase antara $8 \%-11 \%$ dari kejadian kebakaran pada area studi. Persentase jarak dari kanal dengan tingkat kerawanan rendah pada kelas kerawanan rendah pada semua jarak tidak memiliki pengaruh berarti terhadap kelas kerawanan kebakaran. Penelitian ini membuktikan bahwa jarak kanal memengaruhi kejadian kebakaran hutan. Hasil penelitian sesuai dengan pendapat Hooijer et al., (2014) bahwa pada jarak 200-600 meter dari kanal memiliki hubungan yang kuat dengan kejadian kebakaran. Semakin dekat dengan kanal maka gambut yang terbakar semakin dalam, menurut Hooijer et al., (2014) rata-rata kedalaman gambut yang terbakar pada jarak kanal 200-900 meter sedalam 0.38 meter, sedangkan rata-rata kedalaman gambut yang terbakar dengan jarak lebih dari 600 meter memiliki kedalaman 0.20 meter.

Tabel 5 Luas kerawanan kebakaran pada kedalaman gambut dan luas berdasarkan tingkat kerawanan kebakaran

\begin{tabular}{llrrrrrr}
\hline \multirow{2}{*}{$\begin{array}{c}\text { Kedalaman } \\
\text { Gambut }(\mathrm{cm})\end{array}$} & Jenis Gambut & \multicolumn{2}{c}{$\begin{array}{c}\text { Kelas kerawanan } \\
\text { rendah }\end{array}$} & \multicolumn{2}{c}{$\begin{array}{c}\text { Kelas kerawanan } \\
\text { sedang }\end{array}$} & \multicolumn{2}{c}{$\begin{array}{c}\text { Kelas kerawanan } \\
\text { tinggi }\end{array}$} \\
\cline { 3 - 8 } & & $\%$ & \multicolumn{1}{c}{ Luas $^{(\mathrm{a})}$} & $\%$ & Luas $^{(\mathrm{a})}$ & $\%$ & Luas $^{(\mathrm{a})}$ \\
\hline $50-100(20 / 80)$ & Hemist/mineral & 0 & 624 & 1 & 50,648 & 0 & 57,110 \\
$50-100(60 / 40)$ & Hemist/Fibrist & 0 & 7,839 & 0 & 4,293 & 0 & 143 \\
$50-100(80 / 20)$ & Hemist/mineral & 1 & 40,037 & 7 & 23,350 & 0 & 1,579 \\
$100-200$ & Hemist/fibrist & 0 & 2,968 & 6 & 58,738 & 1 & 10,590 \\
$200-400$ & Hemist/Fibrist & 0 & 846 & 0 & 683 & 2 & 11,042 \\
$400-800$ & Hemist/Fibrist & 1 & 4,761 & 5 & 54,068 & 64 & 272,052 \\
$800-1,200$ & Hemist/fibrist & 3 & 99,017 & 0 & 1,734 & 0 & 1,529 \\
\hline
\end{tabular}

${ }^{\mathrm{a} L u a s}$ dalam hektar

Tabel 6 Luas kerawanan kebakaran di jarak terhadap kanal dan luas berdasarkan tingkat kerawanan kebakaran

\begin{tabular}{crrrrrr}
\multirow{2}{*}{ Jarak kanal (meter) } & \multicolumn{2}{c}{ Kelas kerawanan rendah } & \multicolumn{2}{c}{ Kelas kerawanan sedang } & \multicolumn{2}{c}{ Kelas kerawanan tinggi } \\
\cline { 2 - 6 } & $\%$ & Luas $^{(\mathrm{a})}$ & $\%$ & Luas $^{(\mathrm{a})}$ & $\%$ & Luas $^{(\mathrm{a})}$ \\
\hline 100 & 0 & 3,658 & 0 & 867 & 3 & 5,755 \\
200 & 0 & 3,712 & 0 & 859 & 13 & 5,717 \\
300 & 0 & 3,720 & 0 & 905 & 8 & 5,721 \\
400 & 0 & 3,735 & 0 & 955 & 8 & 5,719 \\
500 & 0 & 3,714 & 0 & 964 & 8 & 5,733 \\
600 & 0 & 3,467 & 0 & 980 & 10 & 5,460 \\
700 & 0 & 3,381 & 0 & 1,000 & 8 & 5,406 \\
800 & 0 & 3,328 & 0 & 1,002 & 10 & 5,413 \\
900 & 0 & 3,257 & 0 & 999 & 10 & 5,359 \\
1,000 & 0 & 3,036 & 0 & 920 & 8 & 5,306 \\
1,100 & 0 & 2,806 & 0 & 835 & 5 & 5,274 \\
1,200 & 0 & 2,731 & 0 & 795 & 5 & 5,204 \\
1,300 & 0 & 2,769 & 0 & 763 & 5 & 5,119 \\
\hline
\end{tabular}

${ }^{\mathrm{a}}$ Luas dalam hektar 
Hasil penelitian pada Tabel 7 menunjukkan bahwa persentase kerawanan tertinggi pada kelas kerawanan tinggi berada pada fungsi kawasan hutan lindung sebesar $40 \%$ dari kejadian kebakaran pada daerah area studi. Persentase kelas kerawanan rendah pada kelas kerawanan rendah berada pada fungsi kawasan Kawasan Suaka Alam (KSA) sebesar 3\% dari kejadian kebakaran pada daerah studi. Tingginya kelas kerawanan kebakaran pada fungsi kawasan hutan sejalan dengan penelitian Febriani et al., 2017 yang mengungkapkan bahwa luasan hutan yang hilang sejak tahun 2000 sampai 2015 di dominasi perubahan hutan menjadi semak belukar dan rumput serta perkebunan. Perubahan hutan menjadi semak belukar dan rumput memiliki presentase terbesar dalam perubahan penggunaan lahan hal tersebut mengindikasikan area deforestasi dibiarkan saja setelah diambil kayunya (Febriani et al., 2017). Fungsi kawasan hutan lindung perlu mendapatkan perhatian dalam pengendalian kebakaran hutan untuk menghindari dampak kerusakan ekologis khususnya spesies yang terancam punah.

Tabel 7 Luas kerawanan kebakaran terhadap fungsi kawasan dan luas berdasarkan tingkat kerawanan kebakaran.

\begin{tabular}{lrrrrrr}
\hline \multirow{2}{*}{ Fungsi Kawasan } & \multicolumn{2}{c}{ Kelas kerawanan rendah } & Kelas kerawanan sedang & \multicolumn{2}{c}{ Kelas kerawanan tinggi } \\
\cline { 2 - 7 } & $\%$ & Luas & $\%$ & Luas & $\%$ & Luas \\
\hline APL $^{(\mathrm{a})}$ & 0 & 110,758 & 3 & 29,592 & 8 & 29,047 \\
$\mathrm{HL}^{(\mathrm{b})}$ & 0 & 29,509 & 2 & 31,806 & 40 & 156,061 \\
$\mathrm{HP}^{(\mathrm{c})}$ & 1 & 101,336 & 11 & 38,663 & 8 & 95,643 \\
$\mathrm{HPK}^{(\mathrm{d})}$ & 0 & 42,016 & 3 & 21,825 & 0 & 1,634 \\
$\mathrm{HPT}^{(\mathrm{e})}$ & 0 & 5,792 & 0 & 2,245 & 1 & 1,519 \\
KSA $^{(\mathrm{f})}$ & 3 & 104,692 & 3 & 21,249 & 24 & 103,254 \\
\hline
\end{tabular}

${ }^{\mathrm{a}} \mathrm{APL}=$ Area Penggunaan Lain, ${ }^{\mathrm{d}} \mathrm{HPK}=$ Hutan Produksi yang dapat dikonversi,

${ }^{\mathrm{c}} \mathrm{HP}=$ Hutan Produksi tetap, ${ }^{\mathrm{e}} \mathrm{HPT}=$ Hutan produksi terbatas, ${ }^{\mathrm{f}} \mathrm{KSA}=$ Kawasan Suaka Alam,

${ }^{\mathrm{b}} \mathrm{HL}=$ Hutan Lindung. Luas dalam hektar

Tabel 8 Luas kerawanan kebakaran terhadap jarak jalan dan persentase luas berdasarkan tingkat kerawanan kebakaran

\begin{tabular}{crrrrrr}
\hline \multirow{2}{*}{ Jarak jalan $(\mathrm{km})$} & \multicolumn{2}{c}{ Kelas kerawanan rendah } & \multicolumn{2}{c}{ Kelas kerawanan sedang } & \multicolumn{2}{c}{ Kelas kerawanan tinggi } \\
\cline { 2 - 6 } & $\%$ & Luas $^{(\mathrm{a})}$ & $\%$ & Luas $^{(\mathrm{a})}$ & $\%$ & Luas $^{(\mathrm{a})}$ \\
\hline 1 & 0 & 73,256 & 35 & 54,222 & 12 & 54,307 \\
2 & 0 & 55,609 & 16 & 24,853 & 12 & 32,047 \\
3 & 50 & 44,164 & 8 & 14,969 & 12 & 24,922 \\
4 & 0 & 32,929 & 30 & 8,886 & 22 & 23,065 \\
5 & 50 & 24,418 & 5 & 5,081 & 4 & 22,215 \\
6 & 0 & 19,197 & 0 & 2,521 & 3 & 22,413 \\
7 & 0 & 14,784 & 3 & 2,077 & 1 & 22,432 \\
8 & 0 & 11,530 & 3 & 3,713 & 2 & 20,048 \\
9 & 0 & 9,191 & 0 & 4,198 & 4 & 18,427 \\
10 & 0 & 8,473 & 0 & 4,829 & 4 & 16,438 \\
11 & 0 & 7,891 & 0 & 4,767 & 3 & 15,132 \\
12 & 0 & 6,933 & 0 & 4,389 & 7 & 14,171 \\
13 & 0 & 5,637 & 0 & 3,721 & 8 & 12,730 \\
14 & 0 & 4,573 & 0 & 3,539 & 9 & 11,232 \\
\hline
\end{tabular}

${ }^{a}$ Luas dalam hektar 
Tingginya persentase luas hutan lindung yang tergolong kelas kerawanan tinggi karena kawasan tersebut mengalami perubahan penggunaan lahan menjadi perkebunan dan ladang pada data riil lapangan.Hutan produksi juga memiliki persentase tinggi pada kelas kerawanan sedang dan tinggi. Hutan produksi merupakan daerah yang open access dimana kepemilikan lahan dikuasai oleh pemerintah, namun secara de facto di lapangan keberadaannya dimiliki oleh non-pemerintahan, keadaan seperti ini menyebabkan daerah tersebut lebih rentan terhadap kejadian kebakaran.

Hasil penelitian pada Tabel 8 menunjukkan bahwa persentase jarak jalan dengan tingkat kerawanan tinggi pada kelas kerawanan tinggi berada pada jarak antara 1-4 km dari jalan, dengan besar persentase sebesar 12-22\% dari kejadian kebakaran di area penelitian. Persentase pada kelas kerawanan rendah pada kelas kerawanan tinggi berada pada jarak 6-10 km dari jarak jalan

Tingginya persentase kebakaran pada jarak 1-4 km merupakan jarak yang ideal bagi masyarakat untuk melakukan aktivitas pembakaran lahan. Menurut Prayoto et al., (2017) pada jarak 1-5 km dari jalan banyak ditemukan kejadian kebakaran dibandingkan dengan jarak $>20 \mathrm{~km}$ dari jalan. Hughes (2018) dalam penelitiannya mengungkapkan bahwa, kurangnya kontrol pada pembukaan jalan merupakan faktor utama terhadap deforestasi di Indonesia. Beberapa tahun belakangan ini di Indonesia dan Malaysia menurut Hughes (2018) banyak daerah yang mengalami deforestasi dengan adanya pembukaan jalan baru untuk kemudian dibuat perkebunan kelapa sawit.

Variabel seperti jarak jalan, jarak kanal merupakan variabel yang terjadi akibat perbuatan manusia yang berpengaruh terhadap kebakaran hutan lahan. Manusia menggunakan api untuk membuka area hutan, yang kemudian digunakan untuk membersihkan lahan untuk pertanian dan memenuhi kebutuhan hidupnya (Prayoto et al., 2017; Hooijer et al., 2014; Dohong et al., 2017).

Pengolahan data mining dengan metode sequence pattern mining memengaruhi hasil akhir variabel penyebab kebakaran hutan di area studi. Titik panas yang diolah memiliki predikasi tinggi terhadap kejadian kebakaran, menurut (Wang dan Cheng 2008), data mining merupakan strategi yang cerdas untuk digunakan untuk memadamkan kejadian kebakaran sehingga dapat menentukan sebuah keputusan.

\section{KESIMPULAN}

Pengujian terhadap enam variabel yang diduga dapat menyebabkan kebakaran hutan dan lahan pada area studi, diperoleh empat variabel yang signifikan mempengaruhi kebakaran hutan dan lahan, yaitu : kedalaman gambut, jarak kanal dan fungsi kawasan dan jarak jalan.

Pemodelan spasial yang dibuat pada penelitian terbentuk dari 3 kelas kerawanan (rendah, sedang, dan tinggi) kebakaran yang diperoleh dari variabel-variabel penyebab kebakaran dan kepadatan pola sekuens titik panas. Hasil pemodelan spasial pada lahan gambut diketahui bahwa kejadian kebakaran banyak terjadi pada area gambut dalam pada kedalaman 400-800 $\mathrm{cm}$. Hasil pemodelan spasial pada jarak kanal diketahui bahwa jarak 100-900 meter dari kanal memengaruhi kebakaran. Fungsi kawasan hutan benyak terjadi kejadian kebakaran, dibandingan fungsi kawasan lain. Kejadian kebakaran terhadap jarak jalan banyak terjadi pada jarak 1-4 km dari jalan. 


\section{DAFTAR PUSTAKA}

Cattau ME, Harrison ME, Shinyo I, Tungau S, Uriarte M, DeFries R. 2016. Source of antropogenic fire ignitions on the peat-swamp landscape in Kalimantan, Indonesia. Journal of Global Environmental Change. 39(2016): 250 - 219.

Cortez P, Morais A. 2007. A Data Mining Approach to Predict Forest Fires Using Meteorogical Data. Proceedings of the $13^{\text {th }}$ EPIA Portuguese Conference on Artificial Inttelegence. 512 - 523

Chuvieco E, Aguado I, Jurdao S, Pettinari ML, Yebra M, Salas J, Hantson S, Riva JDL, Ibarra P, Rodrigues M, Echeverria M, Azqueta D, Roman MV, Bastarrika A, Martinez S, Recondo C, Zapico E, Martinez-Vega FJ. 2014. Integrating geospatial information into fire risk assessment. International Journal of Wildland Fire. 23(5): 606 - 619.

Dohong A, Aziz AA, Dargusch P. 2017. A review of the drivers of tropical peatland degradation in South-East Asia. Journal of Land Use Policy. 69(2017): 349-360.

Hooijer AL, Page S, Navratil P, Vernimmen R, Van der vat M, Tansey K, Konecny K, Siegert F, Ballhorn U, Mawdsley N. 2014. Carbon emssion from drained and degraded peatland in Indonesia and emission factor for measurement, reporting and verification (MRV) of peatland greenhouse gas emissions. [Scientific Paper] Indonesia (ID): Indonesia - Australia Kalimantan Forest Carbon Partnership.

Hoscilo A, Page SE, Tansey KJ, Rieley JO. 2011. Effect of repeated fires on land-cover change on peatland in southern Central Kalimantan, Indonesia, from 1973 - 2005. International Journal of Wildland Fire. 578-588.

Hughes AC. 2018. Have indo - malaysian forests reached the end of the road? Journal Biological Conservation. 223(2018): 129 - 137.

Indriani F, Prasetyo LB, Dharmawan AH. 2017. Analisis deforestasi menggunakan regresi logistik model di Tahura sekitar Tanjung Provinsi Jambi. Jurnal Pengelolaan Sumberdaya Alam dan Lingkungan. 7(3): 195-203.

Jaya INS, Purnama ES, Arianti I, Boonyanuphap, J. 2007. Forest fire risk assessment model and post - fire evaluation using remote sensing and gis : a case study in Riau, West Kalimantan, and East Kalimantan Provinces, Indonesia. [Project Research]. Finlandia (FI) : University of Helsinki.

Mapilata E, Gandasasmita K, Djajakirana G. 2013. Analisis daerah rawan kebakaran hutan dan lahan dalam penataan ruang di kota Palangka Raya provinsi Kalimantan Tengah. Majalah Ilmiah Globe. 15(2):178 - 184 .

Mukti A, Prasetyo LB, Rushayati SB. 2016. Mapping Fire Vulnerability in Alas Purwo National Park.Procedia Environmental Science (33): 290 - 304.

Nurulhaq NZ, Sitanggang IS. 2015. Sequential pattern mining on titik panas data in Riau Province using the Prefixspan algorithm. International Conference on Adaptive and Intelligent Agroindustri (ICAIA) $21053^{\text {rd }}$ International Conference pp. 257 - 250. [terhubung berkala]. https://www.researchgate.net/ [2016 July 23]. 10.1109/ICAIA.2015.7506517.

Prasasti I, Boer R, Ardiansyah M, Buono A, Syaufina L, Vetrita Y. 2012. Analisis hubungan kode kode SPBK (sistem peringkat bahaya kebakaran) dan hotspot dengan kebakaran hutan dan lahan di Kalimantan Tengah. Jurnal Pengelolaan Sumbberdaya Alam dan Lingkungan. 2(2): $91-101$.

Prayoto, Ishihara MI, Firdaus R, Nakagoshi N. 2017. Peatland fires in Riau, Indonesia, in relation to land cover type, land management, landholder, and spatial management. Journal of Environmental Protection. 8(2017): 1312 - 1332. 
Samsuri. 2008. Model spasial tingkat kerawanan kebakaran hutan dan lahan (studi kasus di wilayah Propinsi Kalimantan Tengah). Disertasi. Sekolah Pascasarjana. Bogor(ID): Institut Pertanian Bogor.

Shi Y, Sasai T, Yamaguchi Y. 2014. Spatio-temporal evaluation of carbon emission from biomass burning in Southeast Asia during period 2001 - 2010. Journal Ecological Modelling. 272(2014): $98-115$.

Setiawan I, Mahmud AR, Mansor S, Shariff ARM, Nuruddin AA. 2004. GIS-grid based and multi criteria analysis for identifying and mapping swamp forest fire hazard in Pahang, Malayasia. Disaster and Prevention Management. 13(5): 379 - 386.

Sumarga E. 2017. Spatial indicators for human activities may explain the 2015 fire hotspot distribution in central kalimantan Indonesia. SAGE Publication Journal Tropical Conservation Science. 10: 1-9.

Syaufina L. 2008. Kebakaran hutan dan lahan di Indonesia: Perilaku api, penyebab dan dampak kebakaran. Malang (ID): PT Bayu Media.

Tacconi L. 2016. COMMENTARY: Preventing fires and haze in southeast asia. Nature Climate Change. 6(7): 640-643.

Wooster MJ, Perry GLW, Zoumas A. 2012. Fire, drought and el-nino relationship to borneo (southeast - asia) in the pre-MODIS era (1980 - 2000). Biogeosciences 9(1): 317-340.

Zhao Q, Bhownick SS. 2003. Sequential pattern mining: a survey. ITechnical report CAIS Nanyang Technological UniversitySingapore (1). 